\title{
Impact Analysis of the People's Gold Mine on Economic, Socio-Cultural, and Public Health in Poboya, Central Sulawesi
}

\author{
Juraid Abdul Latief ${ }^{1}$, Syahir Natsir ${ }^{2}$, Mery Napitupulu ${ }^{3}$, Asriani Hasanuddin ${ }^{4}$, Riady $^{2}$ \\ Ibnu Khaldun ${ }^{5}$ \\ \{juraidalatief@yahoo.com¹, syahirnatsir@gmail.com², merytn@gmail.com ${ }^{3}$, asrianihasan@yahoo.com ${ }^{4}$, \\ riadyibnukhaldun@ rocketmail.com ${ }^{5}$ \} \\ ${ }^{1,3}$ Faculty of Teachers Training and Education, Tadulako University, Jl. Soekarno-Hatta KM.9, \\ Tondo, Mantikulore, Kota Palu, Sulawesi Tengah 94148, Indonesia \\ ${ }^{2}$ Faculty of Economy, Tadulako University, Jl. Soekarno-Hatta KM.9, Tondo, Mantikulore, Kota \\ Palu, Sulawesi Tengah 94148, Indonesia \\ ${ }^{4}$ Faculty of Fishery and Animal Science, Tadulako University, J1. Soekarno-Hatta KM.9, Tondo, \\ Mantikulore, Kota Palu, Sulawesi Tengah 94148, Indonesia \\ ${ }^{5}$ Faculty of Social and Political Science, Sulawesi Barat University, Jl. Prof. Dr. Baharuddin \\ Lopa, S.H., Kabupaten Majene, Sulawesi Barat 91412, Indonesia
}

\begin{abstract}
This study aims to describe the impact of the gold mine on the economic, social, cultural and public health conditions in Poboya village of Central Sulawesi. The data were collected through interviews, observation, and documentation. The results showed that the existence of the gold mine in Poboya had an impact on the shifting of community work from farmers to gold miners which led to increased income and economic multipliers for other activities. The social impact caused was the rapid flow of migrants to Poboya but the potential for conflict was almost non-existent due to the large influence of the authorities in regulating mining activities in this region. In addition, the impact on the health sector is that 374,082 residents of Palu are at low level of risk due to increased mercury levels in the atmosphere, contamination into the food chain, and increased levels of mercury in the water.
\end{abstract}

Keyword: Economic, Social, Cultural and Public Health

\section{Introduction}

Indonesia has mineral-rich land that is always rejuvenated and enriched by materials released by volcanoes. It also contains various industrial raw materials of minerals such as tin, lead, aluminum ore, nickel, copper and asbestos, gold, silver, manganese, quartz, limestone, sulfur, and others. There are a number of things needed to be considered. The natural resources possessed is not inherited from ancestors to be spent for granted but it must be inherited from generation to generation in a complete condition because the use of resources inadvertently can harm human interests in the present and in the future. One of them is Poboya in Central Sulawesi [1]

Poboya is one of villages in East Palu district, Palu City, Central Sulawesi, Indonesia. This area is a water buffer zone for Palu and its surroundings. It is one of the villages located 
in Mantikulore Sub-District, Palu, Central Sulawesi. In 2000, it became a public spotlight due to mining activities in this area as a result of the discovery of gold. This caused many people in the area to switch professions from farmers of various commodities, such as corn, onions, candlenuts and coconuts, to become gold miners. At present, Poboya has undergone many changes both from the shape of the land and the economic life of its people. Changes in landforms can be seen from the shapes of its mountains which have been eroded due to continuous mining activities.

The village is bordered by four regions, namely Palu City, Donggala Regency, Parigi Moutong Regency and Sigi Regency. Now it has become an area of uncontrollable gold mining activities. Poboya, which used to be an agricultural area with a stretch of rice fields and community gardens, is now filled with gold processing machines and gaping holes from excavations of the miners. Gold mining is one of the livelihoods of Poboya residents who used to be farmers. The change in the source of income began with the discovery of gold in the Poboya area.

From the economic standpoint, based on the amount of gold obtained, with the price of gold which relatively increased at any time, it certainly greatly affects the income of the community. The positive impact of mining activities including the increase in Regional Original Income, the creation of jobs and economic improvement for communities around the mining area [2]. Income earned by each individual usually has differences due to age, inherited characteristics, courage to take risks, amount of practice, wealth and inheritance, market balance and discrimination [3]. This is the reason why the researcher was interested in researching and compiling this article with the aims of gathering information about the impact of gold mining on the socio-economic community in Poboya, being discussed by the people of Palu and surrounding areas, and producing accurate information regarding the impact of gold mining in Poboya because at this time the region has experienced changes in both the shape of the land and the socio-economic life of the community.

The landform changes can be seen from the mountain shapes in this region at this time. The mountains around the area have been greatly eroded due to continuous mining activities. Study changes in the community environment, it is necessary to know the reasons behind the changes [4]. If it is examined more deeply about the causes of changes in the community environment, perhaps this is because there is something considered to be no longer satisfying, there are new factors that satisfy the community better as a substitute for the older one, there may factors in the community itself, and some are maybe from outside of internal factors and external factors. The people's gold mining activities basically can improve their economic conditions but can also provide threats to environmental damage and pollution as well as several other social problems including in the health sector. The potential for environmental damage, in many cases is the reason for the rejection of mining by the local community [5].

In the social life of society, there have been drastic changes. Social life adjusted to their high income makes the community more individual. Promiscuity of teenagers is also increasingly prevalent due to the lack of control from parents who are busy pursuing high income becoming gold miners. Based on the results of the field survey and strengthened by the results of Zurhaar's research [6], it showed that since the rise of mining projects in the Poboya region, people's lives have changed. It has made their social life hard, no longer safe and harmonious. People also compete with each other, causing their households to fall apart. Furthermore, lots of teenagers get along with no restrictions and places of illegal prostitution are not difficult to find. This is because the family leaders are busy to invest in participating in exploration with the aim of gaining higher income as a gold miner. Based on the description 
above, it is necessary to do research on the impact of gold mining on the economy, socioculture, and health of the community in Poboya.

\section{Research Methods}

This study used a descriptive approach to describe the conditions related to the impact of gold mining on the socio-economic life of the community in the Poboya village in accordance with the situation as it is. Descriptive approach is aimed at making a description of social or natural phenomena factually and accurately. The research on the socio-economic impacts was carried out using qualitative method analysis with the data collection process, they were: 1) the use of in-depth interviews technique with people living around the gold mining area; 2) direct observation in the field; 3) and documentation of conditions in the field. The data used was not only primary data in the form of interviews and observations but also secondary data obtained from several documents from previous research. The steps taken to examine the socio-economic and environmental impacts on communities in the Poboya mining area were as follows:

\subsection{Literature Review}

Before conducting observations in the field, the researcher conducted a study of the literature of several documents both originating from the results of studies of several previous research results, and other supporting documents.

\subsection{Observation}

Observation as a data collection technique has specific characteristics when compared to other techniques. Then observations were made on changes in the social activities of the community in the Poboya region;

\subsection{In-depth Interview}

In-depth interviews are methods of collecting data by asking something to someone who is an informant by using interview guidelines. Guidelines are used to remind researchers of aspects that must be discussed, also become a checklist whether the relevant aspects have been discussed or asked. With such guidelines, researcher must think about how the questions will be explained in concrete terms in the question sentences while adjusting the questions contextually when the interview takes place. The study team has conducted interviews with elements of the community and government officials in Poboya village;

\subsection{Documentation}

This method is a way of collecting data that produces important records relating to the problem under study so that complete data is obtained, valid and not based on estimates. Therefore, documents are sources of data that can be used to analyze, interpret and even predict. The documents utilized in this research had come from various sources as long as they related to this research.

\section{Analysis of Various Gold Mining Impacts in Poboya}

\subsection{Economic Impact}

In law number 4 of 2009 concerning mining of minerals and coal, it is explained that in order to support sustainable national development, one of the objectives of mineral 
management is to increase the income of indigenous peoples, regions and countries as well as create employment opportunities as breadth. Aiming to improve people's welfare and to achieve these goals mining activities must always respect the principles of sustainable and insightful environmental development.

Likewise, the traditional gold mining activities in Poboya area are expected to have a real economic impact in the form of increasing community income, local government revenues, and opening employment opportunities as wide as possible so that people's welfare increases.

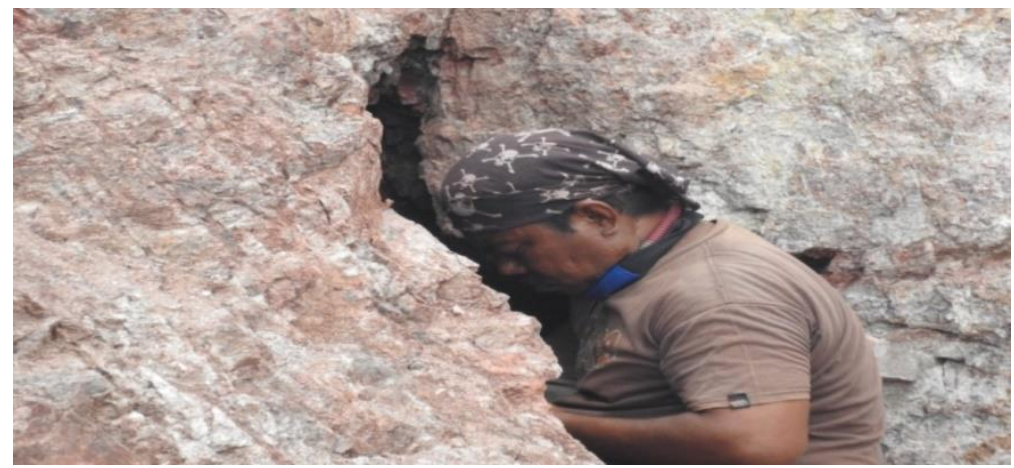

Fig.1. Poboya Mine Worker

The rise of mining activities has changed the face of Poboya, growing into a small city that attracts many people. In addition, these activities also create multiplier economic effects such as the creation of economic opportunities (directly related to mining activities such as investment demand for production equipment, lighting equipment, transportation facilities, and the establishment of buildings for the production process as well as the workers' housing) and also indirect impacts such as the growth of various informal business sectors to meet the needs of workers. More details can be seen in Fig 1.

The indigenous people mine to increase their income. Some of them earn money from fees from people going in and out of the mining area, and tromols or barrels rental. In addition, some of them are also transport workers, miners, food vendors, and other service activities. For more details, see the following table:

Table 1. Economic Impacts in Several Aspects

Livelihood Education

Before

1. The focus of people's livelihood in the Poboya area was as farmers with several commodities such as sweet potatoes, onions, corn, and several other commodities;

2. In addition, the people in the village were also active as civil servants in several
1. The average level of education of the community in the Poboya was Junior High School;

2. There were a number of people having education to high school;

3. Only a small number of people could get education up to college.
1. Income earned from activities as a farmer was very minimal with an average income of $\mathrm{Rp}$. 500,000 per month;

2. When compared with income earned as a traditional miner with an average income of $\mathrm{Rp}$. 2,500,000 per month. 
government institutions in in Palu. However, the number was very small compared to those who were active as farmers.
After

Mining activities in Poboya have caused some of its people to switch professions to become traditional miners by relying solely on makeshift tools coupled with the accessible land.
Communities in the village feel assisted in terms of education because of increasing income as traditional miners that stimulate access to higher education, in this case achieving education up to college.
Significant increase in income from activities as traditional miners.

Based on the results of interviews between the researcher and the miners, people in the Poboya area have an average monthly income increase of at least Rp. 500,000-3,000,000 as miners from previously only Rp. 500,000-1,000,000 as farmers. The average income is expressed as income accumulated in some of the income delivered by each informant, so it is found that the income is obtained in one month when active as a gold miner and as a farmer.

\subsection{Social and Cultural Impacts}

The existence of a gold mine in Poboya has an impact on the social and cultural conditions in the region. In the past few years many people from outside Central Sulawesi have come to Poboya to mine. The existence of a gold mine in Poboya is a magnet for people living outside of Palu City to come as traditional miners. They realized easy access to gold mining areas because the mine site is in the center of the city and also has a large gold content [7]. The results of interviews of the researcher with the indigenous people in Poboya village, Rifky (32 years old), stated that:

"Since there is gold mining in Poboya, I have seen lots of people outside Palu coming in this area. I was aware of that because of their unfamiliar accents so I knew that they were not originally from this village."

In addition, the existence of gold mining in Poboya resulted in changes in the main job of the community from farmers to miners and owners of modern mining equipment such as tromol, crusher, and cyanidation. The number of gold miners in Poboya reached 5,000 people and the number of tromols ranged from 20,000 units [8]. The community in Poboya, who used to work as farmers, considered work as farmers no longer supportive. Therefore, many of them started to become miners because they thought they would get greater income.

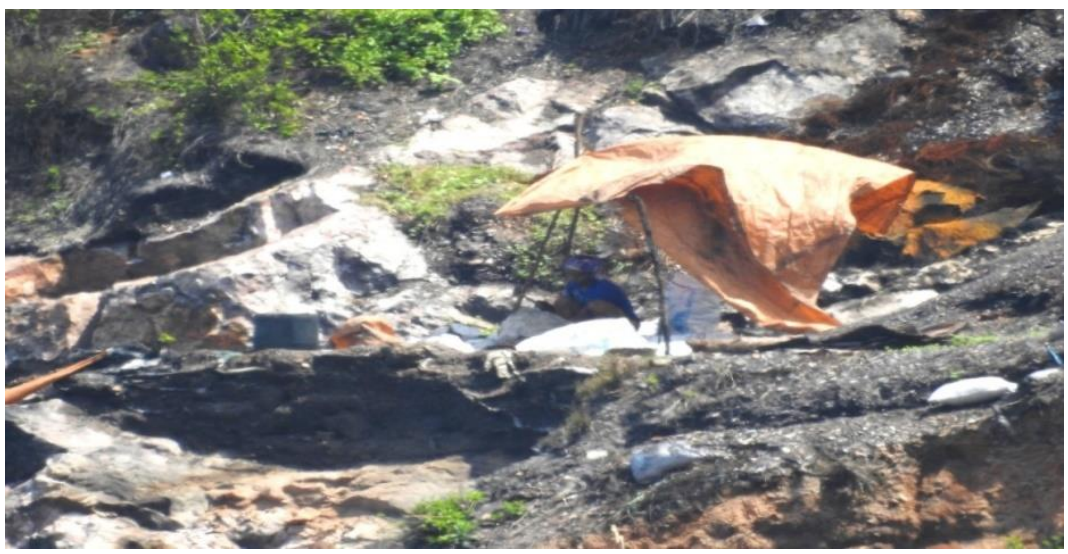


Fig 2. The processing of the Poboya Gold Mine

At present it is estimated that more than 10,000 people have come to Poboya to try their luck as miners. This definitely will influence changes in the structure, culture and social order of the Poboya community. Differences in structure and culture as well as competition between indigenous peoples and migrants can certainly lead to conflict and social tension. Sociologically membership in the same group and the closeness of social status encourage social associations so that the higher the level of heterogeneity and disparity in a society, the greater the obstacles arising for the occurrence of social relations among members or the social integration.

In addition to the heterogeneity factors, the basis for the emergence of conflict in Poboya can occur because many people work in the same space, are not well distributed, and converge on an activity where the benefits of each party are uneven. This can cause a very large chance of conflict because conflict will arise when the distribution of an opportunity is uneven and controlled by a certain group [7]. Likewise, the conflict that occurred in Poboya in 2010 can be a manifestation of the social and cultural impacts that arise as a result of mining activities causing a high flow of people from outside the area to mine, resulting in friction due to inappropriate distribution of land ownership [9]. For more details related to these problems, see the following table:

Table 2. Social Cultural Impacts in the Poboya Mining Area

\begin{tabular}{|c|c|}
\hline Before the existence of mining activities & After the existence of mining activities \\
\hline People tended to work as farmers & The community began to turn into miners \\
\hline - Lack of conflict & - Income increases \\
\hline - $\quad$ Low education & - Higher education \\
\hline - $\quad$ Lack of availability of public facilities & - Availability of public facilities \\
\hline & - Increased potential for conflict \\
\hline & - Increased number of new jobs \\
\hline & - $\quad$ Availability of several public facilities \\
\hline
\end{tabular}

From the explanation in the Table 2, the existence of the gold mining activity in Poboya has given social and cultural impacts for the local community.

\subsubsection{Increased Potential for Conflict}

The location of the Poboya gold mine in the middle of the city has made it easy for people to get to the area. This greatly influences the level of the migration of outside communities both from Palu City and Central Sulawesi Province to go to Poboya. More details can be seen in Fig 3 ..

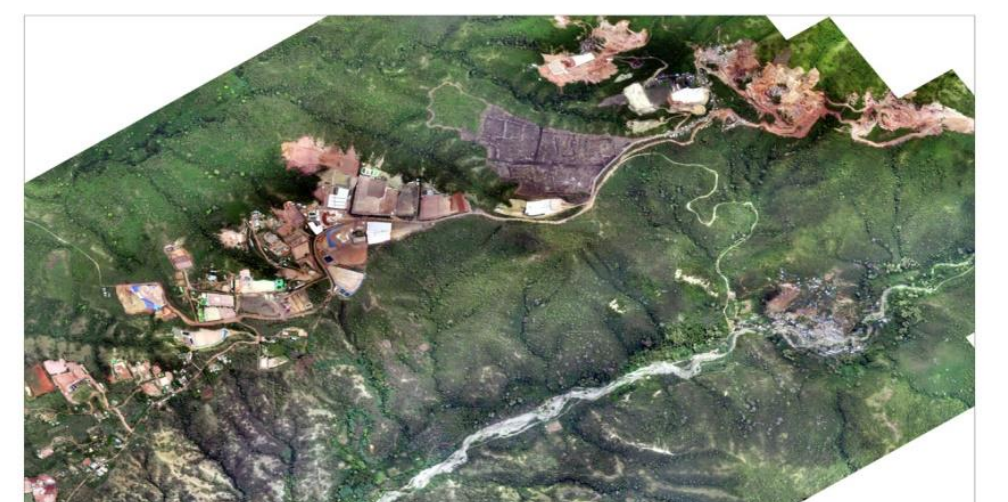


Fig 3. Aerial photo of the Poboya mine location

Gold mines became a magnet for the community to become miners due to considerable profits [10]. Around 2008 there was a large population migration to Poboya from various regions [3]. The results of interviews with a resident in Poboya village, Kaedah (51 years old), stated that:

"I think, after the opening of gold mine access here, more and more people outside the city have come to this village. Personally, I think it is okay as long as they do not disturb us here as the indigenous people."

The high level of migration can lead to friction of interests including cultural differences because everyone coming to be a miner in Poboya from various regions carries distinctive characteristics and identities. Conflict can occur in an area due to the friction of interests including cultural friction because of differences in background and purpose [11]. The large level of migration towards Poboya, if left uninterrupted, will also cause conflict among the community because indigenous people will be marginalized.

In Poboya village there is the Poboya Customary Council which applies customary law to everyone who works in the Poboya community mining area. Those considering to violate customs and morality norms will be subject to customary fines of at least 1-3 goats or returned to their hometown. The enactment of customary law is currently considered quite effective in controlling the behavior of miners in the area because until now no one has received the customary sanctions. However, the problem is how long the existence of the customary council will be able to control the behavior of thousands miners [12].

\subsubsection{Transfer of Employment}

Basically the main livelihood of the people in the Poboya region is as farmers with various types of commodities such as onions, yams, rice, peanuts, and several other types of commodities. Furthermore, most of them consider that just being a farmer cannot provide a high contribution to their income. The presence of access to a gold mine in the area resulted in the community spontaneously experiencing a high change in socio-economic impacts. The gold mine provides great access to changes in welfare, especially increased income because gold is one of the commodities that have a high selling price and is very potential.

From 2000 to 2003 was the initial stage of gold mining activities in Poboya. At this stage it was found that there were only around 50 local people who carried out mining activities in 
the region using sieve technology [9]. Furthermore, massive mining activities occurred in 2013 which caused a change in the shape of the area. This was due to the large number of new land clearing for the expansion of mining land accompanied by an increasing number of miners. In 2014 there were approximately 3,500 active miners with a number of tromols (sieve replacement technology which were considered more efficient in managing gold mining products), reached 20,000 units.

Moving on from these problems, the people in Poboya considers that being a traditional gold miner is one of great accesses to get an increase in welfare. In addition, it is also caused by a low level of difficulty in changing professions to become a traditional miner which is not requiring special requirements and only requiring knowledge that can be obtained through short learning.

Mining activities in Poboya have an impact on environmental damage because gold mining activities basically also carry out logging activities in the mining area for Poboya region is also a forest. One of the significant increases in the number of miners is caused by the issuance of the Palu City Regional Regulation number 03 of 2011 concerning People's Mining, one of which regulates the licensing of exploitation of mining areas for community mining activities. The impact that leads to the occurrence of pollution and environmental damage caused by mining businesses is an important problem that must be considered in order to create environmental preservation as a basis for carrying out environmental protection and other characteristics required to realize sustainable development.

Until now, the Palu government has made efforts to regulate and manage the community mining. However, because of the insistence of community economic factors and limited employment, community mining activities without permits are increasingly developing and difficult to control. The existence of the activities basically can improve the economic condition but can also provide a threat to environmental damage and pollution and several other social problems including in the health sector.

\subsection{Health Impact}

As a result of too many people mining and the lack of regulation from the government, the chances of resource struggles among miners are increasingly out of control. Some of the results of previous studies indicate the level of pollution in Poboya due to chemical use (mercury) is alarming. Laboratory test results of the Central Sulawesi Provincial Health Office noted that Poboya village was contaminated with mercury 0.05 parts per million (ppm), far exceeding the permissible threshold of $0.001 \mathrm{ppm}$ [7]. This is evidenced by the use of mercury in the immersion process in the gold mine. More details can be seen in the following picture [8].

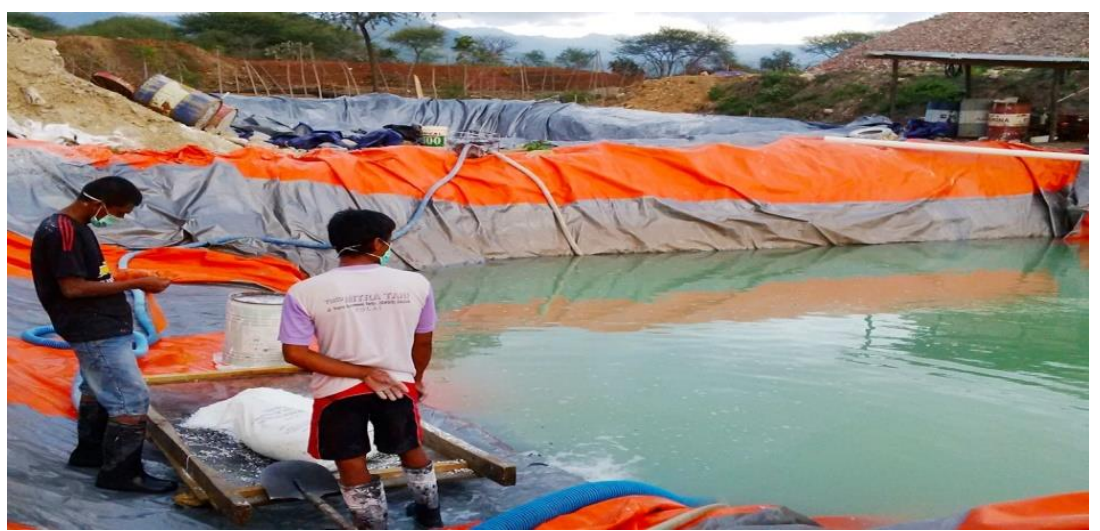


Fig 4. Location of Soaking Pool

The study of an independent team from the Indonesian People's Gold Mining Association found that PDAM water as a source of clean water has been contaminated with 0.005 ppm of mercury. In addition, it was found that the use of mercury in the Poboya gold mine resulted in mercury contamination at several points in the Palu city area which could result in more than 10,000 people in the Poboya region at high risk of mercury poisoning. This number consists of those who live and work in three areas of contamination (especially in Poboya) whose air has been heavily contaminated due to open burning of amalgam, also contamination through direct contact through the skin as well as food and drink. Around 374,082 people living in Palu also face a low level of risk due to increased levels of mercury in the atmosphere, contamination in the food chain, and increased levels of mercury in drinking water. This reality, if not anticipated early, will lead to a larger conflict. In addition, data from the Singgani health center shows that there are 64 people affected by acute respiratory infections caused by this. It is also because of the dust caused by cars that always pass to the mining area in Poboya village [13].

\section{Conclusion}

The results of the study showed that gold mining in Poboya, Palu City, Central Sulawesi Province had an impact on economic conditions, social culture and public health. The impact results: 1) regional economic development and the local people's economy. The results of the research conducted showed that the existence of gold mining caused a shift in the work of local people to become gold miners, there was an increase in income, and the effect of economic multipliers on other activities; 2) the social impact caused is a large population migration to the Poboya area, but the potential for conflict is almost non-existent due to the large influence of the security forces in regulating and supervising mining activities in the region; 3) the gold mining will give a low level of risk to 374,082 people from Palu from increasing levels of mercury in the atmosphere, contamination in the food chain, and increased levels of mercury in the water.

\section{References}

[1] S. K. Moerad and E. Susilowati, "Pemetaan Potensi dan Dampak Ekonomi Masyarakat di Kawasan Pertambangan Bukit Tumpang Pitu Banyuwangi,” pp. 114138.

[2] S. Obiri, P. A. D. Mattah, M. M. Mattah, and F. A. Armah, "Assessing the 
Environmental and Socio-Economic Impacts of Artisanal Gold Mining on the Livelihoods of Communities in the Tarkwa Nsuaem Assessing the Environmental and Socio-Economic Impacts of Artisanal Gold Mining on the Livelihoods of Communities in the," no. April, 2016.

[3] B. Muhammad, H. Uswah, and N. U. R. Isrun, "Gold Mining Activities and Its Impacts on Land Degradation in Central Gold Mining Activities and Its Impacts on Land Degradation in Central Sulawesi Indonesia," no. January 2012, 2018.

[4] G. Journal, H. Resource, M. Vol, E. Centre, and D. Uk, "No Title," vol. 5, no. 7, pp. 11-35, 2017.

[5] D. K. Angreta and F. Firdaus, "Local Community Tactics to Decline the Mining; Evidence from West Sumatra , Indonesia," in WESTECH 2018, 2019.

[6] I. M. C. Report, "ASGM sites : Poboya and Sekotong in Indonesia," no. January, pp. $1-8,2013$.

[7] Z. Sulthan, S. Endriatmo, A. Soeryo, and P. K. Numala, "Contestation and Conflict in the Seizure of Gold in Poboya," J. Sosiol. Pedesaan, vol. 06, no. 02, pp. 145-159, 2012.

[8] D. Village et al., "Impact of the traditional gold mine management on public health and agricultural land: A Study of traditional gold mining in Poboya , Sausu and Impact of the traditional gold mine management on public health and agricultural land : A Study of traditional," no. March 2018, 2017.

[9] B. O. Omisore and D. Ph, "Organizational Conflicts : Causes , Effects and Remedies," vol. 3, no. 6, pp. 118-137, 2014.

[10] J. S. Harington, N. D. Mcglashan, and E. Z. Chelkowska, “A century of migrant labour in the gold mines of South Africa," no. March, pp. 65-72, 2004.

[11] W. Paper, "The impacts of artisanal gold mining on local livelihoods and the environment in the forested areas of Cameroon."

[12] F. Risiko et al., "Risk Factors of Acute Respiratory Infections in Practice Area for Community of Medical Students in Semarang," vol. 11, no. 4, pp. 192-197, 2017.

[13] "Operational guidelines for Prevention and control of ARI in Afghanistan," 2012. 